\title{
Synthesis of Anion-Exchange Materials from Concrete Sludge and Evaluation of Their Ability to Remove Harmful Anions (Borate, Fluoride, and Chromate)
}

\author{
T. Hongo, Y. Tsunashima, A. lizuka, and A. Yamasaki
}

\begin{abstract}
Concrete sludge is an industrial waste slurry containing hydrated cement, aggregates, and water. In the current study, anion-exchange materials: ettringite, metaettringite, and $\mathrm{Ca}-\mathrm{Al}$ layered double hydroxide were synthesized from concrete sludge, and tested to see if they could remove harmful anions (borate, fluoride, and chromate) from solutions. Metaettringite showed high borate and fluoride removal ability, reducing initial concentrations of $100 \mathrm{mg} \mathrm{B} / \mathrm{L}$ and $300 \mathrm{mg} \mathrm{F} / \mathrm{L}$ to $6.3 \mathrm{mg} \mathrm{B} / \mathrm{L}$ and $14.5 \mathrm{mg} \mathrm{F} / \mathrm{L}$. The Ca-Al layered double hydroxide showed high fluoride and chromate removal ability, reducing initial concentrations of $300 \mathrm{mg} \mathrm{F} / \mathrm{L}$ and $180 \mathrm{mg} \mathrm{Cr} / \mathrm{L}$ to $14.5 \mathrm{mg} \mathrm{F} / \mathrm{L}$ and $0.4 \mathrm{mg} \mathrm{Cr} / \mathrm{L}$.
\end{abstract}

Index Terms-Anion exchange material, concrete sludge, harmful anions, ettringite, layered double hydroxide, removal.

\section{INTRODUCTION}

Industrial manufacturing processes generate a considerable amount of wastewater, which contains harmful elements. Wastewater must be treated prior to discharge to the environment. Numerous approaches have been studied for the removal of pollutants from contaminated water [1]-[4]. The removal of harmful ions from contaminated water has been attempted by several researchers, employing a wide variety of techniques [5]-[8]. Ion-exchange resins and chelating agents are often used to remove harmful anions such as phosphate, chromate, borate, and arsenate, but these materials are expensive. Ettringite, metaettringite, and layered double hydroxides (LDHs) have attracted attention as alternative low-cost and high-performance materials for the removal of harmful anions.

Ettringite, $\mathrm{Ca}_{6} \mathrm{Al}_{2}\left(\mathrm{SO}_{4}\right)(\mathrm{OH})_{12} \cdot 26 \mathrm{H}_{2} \mathrm{O}$, is a common hydrated phase of Portland cement. The ettringite structure consists of columns of $\left\{\mathrm{Ca}_{6}\left[\mathrm{Al}(\mathrm{OH})_{6}\right]_{2} \cdot 24 \mathrm{H}_{2} \mathrm{O}\right\}^{6+}$ with the inter-column space (channels) occupied by $\mathrm{SO}_{4}{ }^{2-}$ and $\mathrm{H}_{2} \mathrm{O}$ molecules. The $\mathrm{SO}_{4}{ }^{2-}$ is substitutable for other oxyanions such as $\mathrm{CrO}_{4}{ }^{2-}, \mathrm{AsO}_{4}{ }^{2-}$, and $\mathrm{SeO}_{3}{ }^{2-}$ [9], [10]. Ettringite is thermally unstable and transforms to a less hydrated amorphous phase, $\mathrm{Ca}_{6} \mathrm{Al}_{2}\left(\mathrm{SO}_{4}\right)(\mathrm{OH})_{12} \cdot 11-13 \mathrm{H}_{2} \mathrm{O}$, called metaettringite, at temperatures higher than $120{ }^{\circ} \mathrm{C}$ [11], [12]. Metaettringite has a columnar structure similar to that of ettringite, with closer packing in the $a$ direction. The $\mathrm{SO}_{4}{ }^{2-}$ in metaettringite is also

Manuscript received November 9, 2013; revised February 10, 2014.

T. Hongo is with the Faculty of Science and Engineering, Waseda University, Tokyo, Japan (e-mail: peea.hongo@hotmail.co.jp).

Y. Tsunashima and A. Yamasaki are with the Faculty of Science and Technology, Tokyo, Japan.

A. Iizuka is with Institute of Multidisciplinary Research for Advance Materials, Tohoku University, Miyagi, Japan. substitutable for other anions, such as $\mathrm{B}(\mathrm{OH})_{4}{ }^{-}[13]$.

LDHs are anionic clay minerals, and are also known as hydrotalcite-like compounds. The general chemical formula of LDHs is $\left[\mathrm{M}^{2+}{ }_{1-x} \mathrm{M}^{3+}{ }_{x}(\mathrm{OH})_{2}\right]^{x+}\left(\mathrm{A}^{n-}\right)_{x / n} \cdot m \mathrm{H}_{2} \mathrm{O}$, where $\mathrm{M}^{2+}$ and $\mathrm{M}^{3+}$ are di- and tri-valent cations, respectively. The value of $x$ is equal to the molar ratio of $\mathrm{M}^{2+} /\left(\mathrm{M}^{2+}+\mathrm{M}^{3+}\right)$, and $\mathrm{A}^{n-}$ is an anion [14], [15]. The structure is based on brucite-like hydroxide layers, in which some of the divalent cations have been replaced by trivalent ions, resulting in positively charged sheets [16], [17]. This charge is balanced by intercalated anions in the hydrated interlayer regions, and these anions are exchangeable for other anions such as $\mathrm{AsO}_{4}{ }^{2-}, \mathrm{CrO}_{4}{ }^{2-}$, and $\mathrm{SeO}_{4}{ }^{2-}[18]$.

Concrete sludge is fresh waste concrete in the form of a slurry of hydrated cement and aggregate in water. About $1-2 \%$ of fresh concrete prepared for construction use is discarded as concrete sludge because it is necessary to prepare an excess amount of concrete to avoid shortages at construction sites. Concrete sludge is used as a landfill material after solid/liquid separation followed by neutralization with an acid such as sulfuric acid. This treatment process is costly, and an effective recycling process for concrete sludge is needed.

We recently revealed that sorbents prepared from concrete sludge could remove borate and fluoride from solutions [19], [20]. The removal ability resulted from the ettringite and metaettringite phases contained in the sorbents. In the present study, we synthesized $\mathrm{Ca}-\mathrm{Al}-\mathrm{NO}_{3} \quad \mathrm{LDH}$ $\left(\mathrm{Ca}_{4} \mathrm{Al}_{2}(\mathrm{OH})_{12}\left(\mathrm{NO}_{3}\right)_{2} \cdot 4 \mathrm{H}_{2} \mathrm{O}\right)$, as well as ettringite and metaettringite, from concrete sludge. We then compared the abilities of ettringite, metaettringite, and $\mathrm{Ca}-\mathrm{Al}-\mathrm{NO}_{3} \mathrm{LDH}$ synthesized from the concrete sludge to remove harmful anions such as borate, fluoride, and chromate.

\section{EXPERIMENTAL}

\section{A. Synthesis of Ettringite and Metaettringite from Concrete Sludge}

A model concrete sludge was prepared by mixing $83.3 \mathrm{~g}$ of commercially available Portland cement (supplied by Taiheiyo Cement Corp., Japan) with $250 \mathrm{~mL}$ of water for $1 \mathrm{~h}$ at $25^{\circ} \mathrm{C}$. Aluminum sulfate $(85.0 \%$, Wako Pure Chemical Ind. Ltd.) was added to the concrete sludge to give a molar ratio of $\mathrm{Ca} / \mathrm{Al}=3.2$. The ratio was calculated considering the aluminum content in the raw cement. After addition of aluminum sulfate, the mixed suspension was stirred for $24 \mathrm{~h}$ in a constant temperature bath at $25{ }^{\circ} \mathrm{C}$ to form ettringite. The 
solid phase was then separated from the liquid phase by filtration, washed thoroughly with distilled water, and dried at $40{ }^{\circ} \mathrm{C}$ for $24 \mathrm{~h}$. Metaettringite was prepared by calcination of the obtained ettringite at $175^{\circ} \mathrm{C}$ for $16 \mathrm{~h}$. The synthesized ettringite and metaettringite were denoted as CS-ettringite and CS-metaettringite, respectively. The crystal structures were identified by powder X-ray diffraction (XRD) using a Rigaku RINT-Ultima IV diffractometer with $\mathrm{CuK} \alpha$ radiation.

\section{B. Synthesis of LDH from Concrete Sludge}

A model concrete sludge was prepared by mixing $15 \mathrm{~g}$ of commercially available Portland cement (supplied by Taiheiyo Cement Corp., Japan) with $200 \mathrm{~mL}$ of water for $1 \mathrm{~h}$ at $25^{\circ} \mathrm{C} .50 \mathrm{~mL}$ of $90 \mathrm{wt} . \%$ acetic acid (Wako Pure Chemical Ind. Ltd.) was added to the concrete sludge, and stirred for $1 \mathrm{~h}$ at $100{ }^{\circ} \mathrm{C}$. The obtained suspension was separated into leaching solution and residue by filtration. The concentration of $\mathrm{Ca}$ in the leaching solution was measured by inductively coupled plasma atomic emission spectrometry (ICP-AES; Thermo, iCAP 6000). Aluminum nitrate nonahydrate (Wako Pure Chemical Ind. Ltd.) was added to the leaching solution to give a molar ratio of $\mathrm{Ca} / \mathrm{Al}=2.3$. Then, $2 \mathrm{M} \mathrm{NaOH}$ aqueous solution was added to the solution dropwise at $65^{\circ} \mathrm{C}$, and the final $\mathrm{pH}$ was adjusted to 11.5 . The suspension was stirred at $250 \mathrm{rpm}$ for $18 \mathrm{~h}$ at the same temperature. The mixture was filtered; the solid phase was washed thoroughly with deionized water and dried at $100{ }^{\circ} \mathrm{C}$ for $24 \mathrm{~h}$. The synthesized LDH is denoted as CS-LDH. The crystal structure was identified by powder XRD.

\section{Borate, Fluoride and Chromate Ion Removal Experiments}

Anion removal experiments were conducted using solutions of boric acid $(99.5 \%$; Wako Pure Chemical Industries Ltd., Japan), sodium fluoride (99.0\%; Wako Pure Chemical Industries Ltd., Japan), or potassium chromate (99.0\%; Kanto Chemical Co., Inc) as model wastewaters. The initial concentrations of borate, fluoride, and chromate were set at $100 \mathrm{mg} \mathrm{B} / \mathrm{L}, 300 \mathrm{mg} \mathrm{F} / \mathrm{L}$, and $180 \mathrm{mg} \mathrm{Cr} / \mathrm{L}$, respectively. The removal agent to be tested was added to model wastewater in a polypropylene beaker and stirred at $350 \mathrm{rpm}$ with a magnetic stirrer. The weight ratio of the sample to model wastewater solution was $30 \mathrm{~g} / \mathrm{L}$ for borate, $2.0 \mathrm{~g} / \mathrm{L}$ for fluoride, and $10 \mathrm{~g} / \mathrm{L}$ for chromate removal experiments. The initial concentrations and the weight ratio were determened by preliminary experimental results. Sampling of the solution phase was conducted intermittently through a $0.2-\mu \mathrm{m}$ nitrocellulose filter. The concentrations in the filtrates were measured by ICP-AES for fluoride and chromate, and ion-chromatography (IC; HIC-6A; Shimadzu) for fluoride. The $\mathrm{pH}$ of the solutions was also measured intermettedly. Each experiment was conducted for three times to examine the reproducibility of the results. The experimental results were evaluated by the average of the three measurements. After the experiment, the sample was recovered by filtration, dried, and analyzed with XRD.

\section{RESULTS AND DISCUSSION}

Fig. 1 shows XRD patterns of CS-ettringite,
CS-metaettringite, and CS-LDH. Characteristic peaks attributed to the ettringite phase were observed in CS-ettringite, indicating the ettringite compound was successfully synthesized from concrete sludge. Peaks assigned to gypsum $\left(\mathrm{CaSO}_{4} \cdot 2 \mathrm{H}_{2} \mathrm{O}\right)$ and calcite $\left(\mathrm{CaCO}_{3}\right)$ were observed as well as those corresponding to ettringite. The XRD pattern of the CS-metaettringite showed small diffraction peaks assigned to bassanite $\left(\mathrm{CaSO}_{4} \cdot 0.5 \mathrm{H}_{2} \mathrm{O}\right)$ and calcite. Although the CS-metaettringite was prepared by calcination of the CS-ettringite at $175{ }^{\circ} \mathrm{C}$, the peaks from ettringite disappeared completely and an amorphous halo was observed. This indicates that metaettringite, which is an amorphous material, was formed [21]. The gypsum $\left(\mathrm{CaSO}_{4} \cdot 2 \mathrm{H}_{2} \mathrm{O}\right)$ in CS-ettringite was dehydrated and transformed to bassanite by calcination. Characteristic difference in the surface morphology was not observed between CS-ettringite and CS-metaettringite by scanning electron microscope (SEM) observations. The XRD pattern of the CS-LDH showed characteristic peaks attributed to the $\mathrm{Ca}-\mathrm{Al}-\mathrm{NO}_{3} \mathrm{LDH}$ phase, indicating the $\mathrm{LDH}$ compound was successfully synthesized from concrete sludge. Peaks assigned to katoite $\left(\mathrm{Ca}_{3} \mathrm{Al}_{2}\left(\mathrm{SiO}_{4}\right)(\mathrm{OH})_{8}\right)$ were observed as well as those corresponding to $\mathrm{LDH}$.

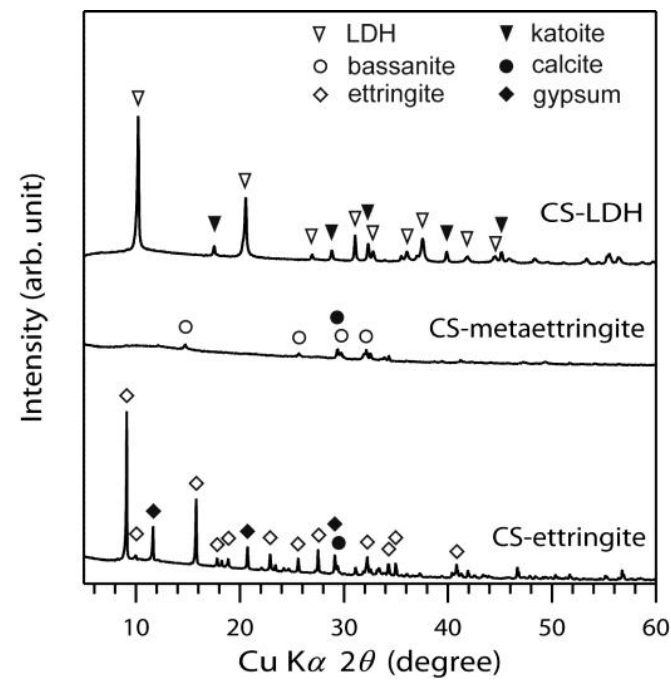

Fig. 1. XRD patterns of the CS-ettringite, CS-metaettringite, and CS-LDH.

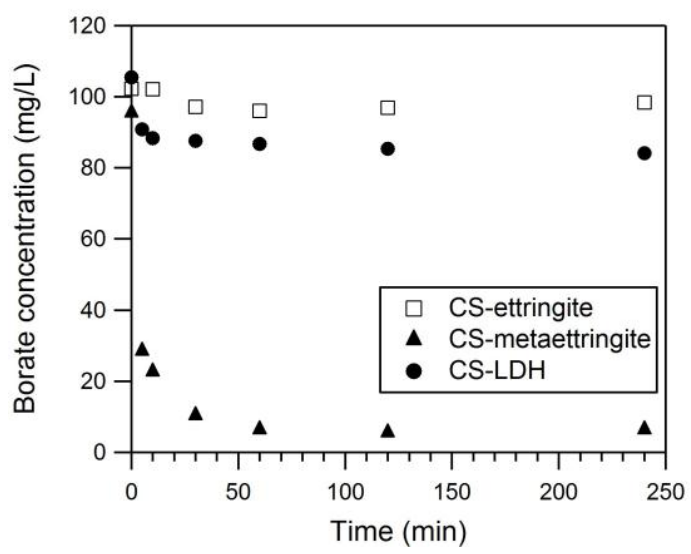

Fig. 2. Borate concentration as a function of time during removal using CS-ettringite, CS-metaettringite, and CS-LDH.

Fig. 2 shows the changes with time in borate concentrations in the aqueous phase during the borate removal experiments. The CS-ettringite showed no noticeable borate removal ability. The concentration of borate after 240 min was 98.4 
$\mathrm{mg} / \mathrm{L}$. With CS-metaettringite as the adsorbent, the concentration decreased immediately, and reached adsorption equilibrium within the first $60 \mathrm{~min}$; the concentration of borate after $240 \mathrm{~min}$ was $6.3 \mathrm{mg} / \mathrm{L}$. The CS-LDH showed some removal ability, and reduced the concentration of borate to $84.1 \mathrm{mg} / \mathrm{L}$ after $240 \mathrm{~min}$. The amounts of borate removed over the 240-min period by the CS-ettringite, CS-metaettringite and CS-LDH were 0.13, 2.97, and 0.71 mg-borate/g, respectively.

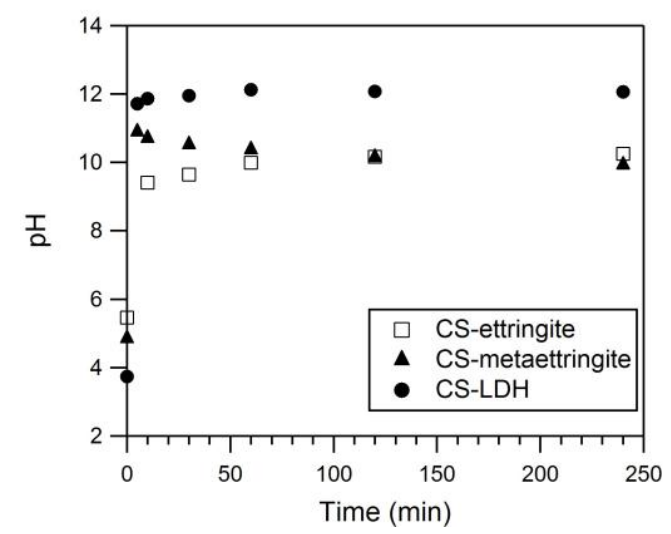

Fig. 3. Changes of $\mathrm{pH}$ during borate removal experiments using the CS-ettringite, CS-metaettringite, and CS-LDH.

Fig. 3 shows changes of $\mathrm{pH}$ during the experiments. A rapid increase of $\mathrm{pH}$ was observed immediately after sample addition, especially for the CS-metaettringite and CS-LDH. The $\mathrm{pH}$ changes of the CS-ettringite were more gradual. The $\mathrm{pH}$ values at $240 \mathrm{~min}$ for $\mathrm{CS}$-ettringite, $\mathrm{CS}$-metaettringite, and CS-LDH were 10.2, 9.9, and 12.0, respectively. This $\mathrm{pH}$ increase is due to the partial dissolution the samples, resulting in the release of $\mathrm{OH}^{-}$. According to the dissociation equilibrium of borate in the aqueous phase, the dominant form of borate under the $\mathrm{pH}$ conditions of this study was $\mathrm{B}(\mathrm{OH})_{4}{ }^{-}$.

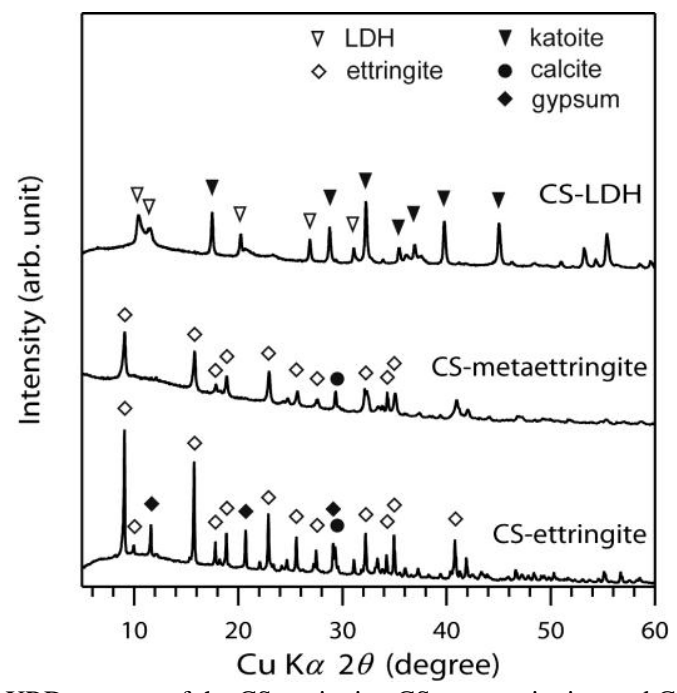

Fig. 4. XRD patterns of the CS-ettringite, CS-metaettringite, and CS-LDH after borate removal.

Fig. 4 shows the XRD patterns of the samples after borate removal experiments. The CS-ettringite showed little change compared with the XRD pattern before borate removal. The CS-metaettringite transformed into crystalline ettringite through hydration; this phenomenon is observed when metaettringite is immersed in water [21], and facilitates the ion exchange of sulfate ions for borate ions in metaettringite
[22]. For the CS-LDH, katoite $\left(\mathrm{Ca}_{3} \mathrm{Al}_{2}\left(\mathrm{SiO}_{4}\right)_{3-x}(\mathrm{OH})_{4 x}\right)$ and LDH phases were observed. The intensities of the diffraction lines from katoite were increased after the borate removal experiment. The (003) diffraction line of the LDH was split into two peaks at around $10.0^{\circ}$ and $11.5^{\circ}$. The peak position of the (003) diffraction line changes with the size of the interlayer anion. The peak at around $11.5^{\circ}$ is assigned to $\mathrm{Ca}-\mathrm{Al}-\mathrm{CO}_{3} \mathrm{LDH}$. The $\mathrm{Ca}-\mathrm{Al}-\mathrm{CO}_{3} \mathrm{LDH}$ was generated by the anion-exchange of $\mathrm{CO}_{3}{ }^{2-}$ in the borate solution for interlayer $\mathrm{NO}_{3}{ }^{-}$in the CS-LDH during the experiment, because $\mathrm{CO}_{3}{ }^{2-}$ is adsorbed onto LDHs in preference to $\mathrm{NO}_{3}{ }^{-}$[18]. The katoite and the $\mathrm{Ca}-\mathrm{Al}-\mathrm{CO}_{3} \mathrm{LDH}$ are considered to barely contribute to the borate removal. The CS-LDH removed the borate by ion exchange for the interlayer $\mathrm{NO}_{3}{ }^{-}$. The broadness of the (003) diffraction line at around $10.0^{\circ}$ can be explained by the coexistence of $\mathrm{B}(\mathrm{OH})_{4}{ }^{-}$(borate) and $\mathrm{NO}_{3}{ }^{-}$(nitrate) in the interlayer, because their ionic sizes are slightly different: $\mathrm{NO}_{3}$ $(0.400 \mathrm{~nm})<\mathrm{B}(\mathrm{OH})_{4}{ }^{-}(0.458 \mathrm{~nm})[23]$.

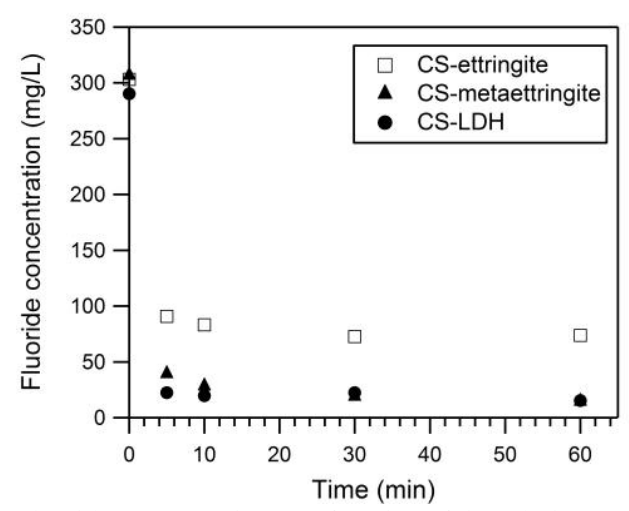

Fig. 5. Fluoride concentration as a function of time during removal using CS-ettringite, CS-metaettringite, and CS-LDH

Fig. 5 shows the changes with time of fluoride concentrations in the aqueous phase during fluoride removal experiments. A decrease in the concentration of fluoride ions was observed for all the samples studied. Using the CS-ettringite as an adsorbent, the concentration reached adsorption equilibrium within the first $30 \mathrm{~min}$, and the concentration after $60 \mathrm{~min}$ was $73.9 \mathrm{mg} / \mathrm{L}$. With the CS-metaettringite or CS-LDH adsorbents, the concentration rapidly decreased within $5 \mathrm{~min}$, and gradually decreased after that. The concentrations after $60 \mathrm{~min}$ for CS-metaettringite and CS-LDH were 14.5 and $14.1 \mathrm{mg} / \mathrm{L}$, respectively. The amounts of fluoride removed over a period of $60 \mathrm{~min}$ by the CS-ettringite, CS-metaettringite, and CS-LDH were 114, 146, and $138 \mathrm{mg}$ fluoride/g, respectively.

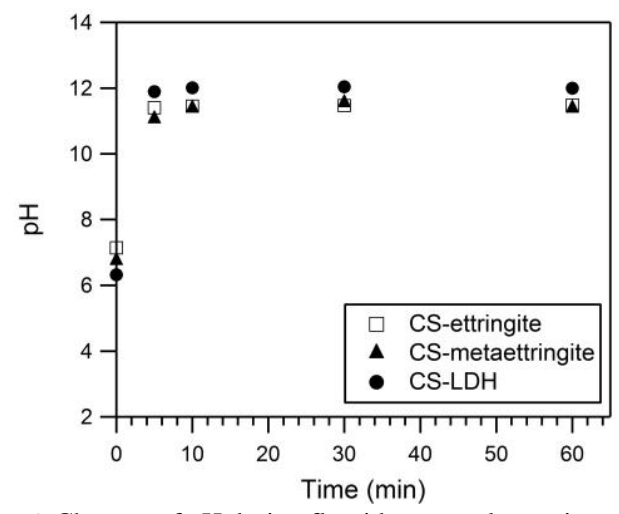

Fig. 6. Changes of $\mathrm{pH}$ during fluoride removal experiments using CS-ettringite, CS-metaettringite, and CS-LDH. 
Fig. 6 shows the changes of $\mathrm{pH}$ during these experiments. A rapid increase of $\mathrm{pH}$ was also observed immediately after sample addition. The $\mathrm{pH}$ values at $60 \mathrm{~min}$ for CS-ettringite, CS-metaettringite, and CS-LDH were 11.5, 11.4, and 12.0, respectively.

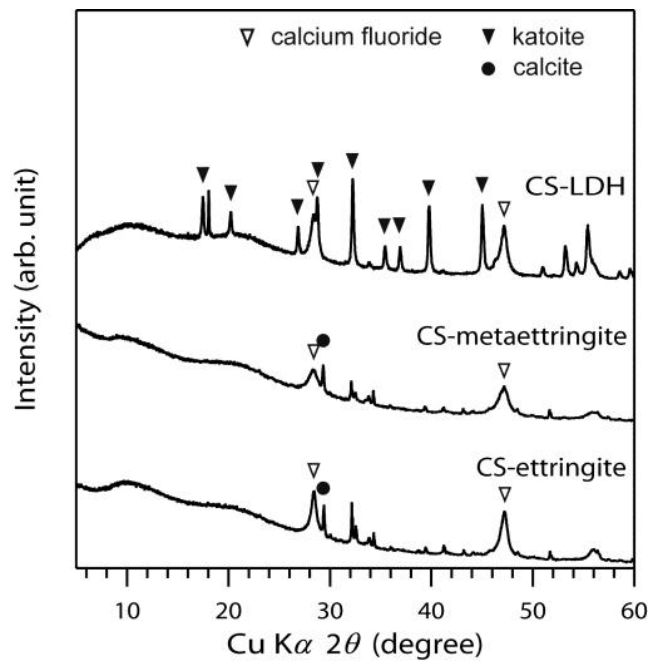

Fig. 7. XRD patterns of the CS-ettringite, CS-metaettringite, and CS-LDH after fluoride removal.

Fig. 7 shows the XRD patterns of the samples after fluoride removal experiments. The diffraction lines assigned to ettringite and $\mathrm{Ca}-\mathrm{Al}-\mathrm{NO}_{3} \mathrm{LDH}$ disappeared from CS-ettringite and CS-LDH, respectively. Instead, diffraction lines for calcium fluoride $\left(\mathrm{CaF}_{2}\right)$ were observed after fluoride ion removal in all three samples. This result indicates that the fluoride ions were removed by precipitation in the form of calcium fluoride.

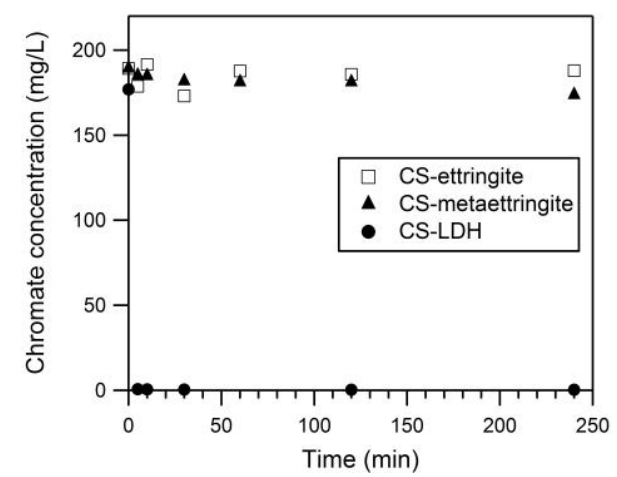

Fig. 8. Chromate concentration as a function of time during removal using CS-ettringite, CS-metaettringite, and CS-LDH.

Fig. 8 shows the changes with time of chromate concentrations in the aqueous phase during the chromate removal experiments. The CS-ettringite and CS-metaettringite showed no noticeable chromate removal ability. The concentrations of chromate after $240 \mathrm{~min}$ were 188.0 and $173.6 \mathrm{mg} / \mathrm{L}$, respectively. Using the CS-LDH as an adsorbent, the concentration decreased rapidly within the initial $5 \mathrm{~min}$, and reached adsorption equilibrium after $60 \mathrm{~min}$. The concentration of chromate after 240 min was $0.4 \mathrm{mg} / \mathrm{L}$. The amounts of chromate removed over a period of $240 \mathrm{~min}$ by the CS-ettringite, CS-metaettringite, and CS-LDH were $0.12,1.56$, and $17.6 \mathrm{mg}$ chromate/g, respectively.

Fig. 9 shows the changes of $\mathrm{pH}$ during these experiments. A rapid increase of $\mathrm{pH}$ was also observed immediately after sample addition. The $\mathrm{pH}$ values at $240 \mathrm{~min}$ for CS-ettringite,
CS-metaettringite, and CS-LDH were 11.0, 10.5, and 12.0, respectively. According to the dissociation equilibrium of chromate in the aqueous phase, the dominant form of chromate under the $\mathrm{pH}$ conditions of this study was $\mathrm{CrO}_{4}{ }^{2-}$.

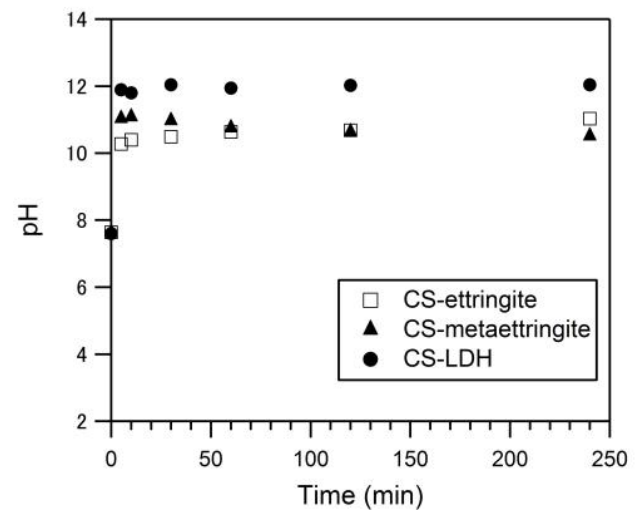

Fig. 9. Changes of $\mathrm{pH}$ during chromate removal experiments using CS-ettringite, CS-metaettringite, and CS-LDH.

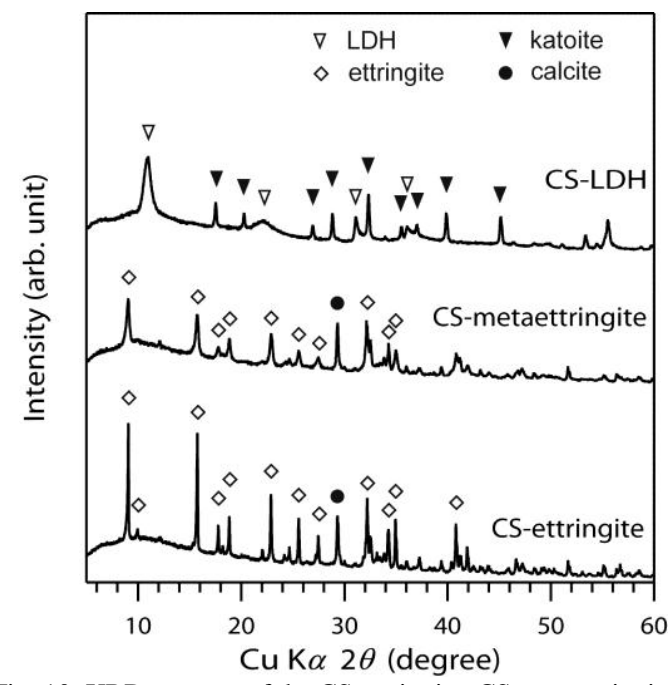

Fig. 10. XRD patterns of the CS-ettringite, CS-metaettringite, and CS-LDH after chromate removal.

Fig. 10 shows the XRD patterns of the samples after chromate removal experiments. The CS-ettringite showed little change compared with the XRD patterns before the chromate removal experiment. The CS-metaettringite transformed to ettringite through hydration. For the CS-LDH, the (003) diffraction line at around $10^{\circ}$ became broader. This can be attributed to the coexistence of $\mathrm{CrO}_{4}{ }^{2-}$ (chromate) and $\mathrm{NO}_{3}{ }^{-}$(nitrate) in the interlayer, because their ionic sizes are also slightly different: $\mathrm{NO}_{3}{ }^{-}(0.400 \mathrm{~nm})<\mathrm{CrO}_{4}{ }^{2-}(0.458 \mathrm{~nm})$ [23]. This result indicated that the ion exchange of nitrate ions for chromate ions occurred.

\section{CONCLUSIONS}

Ettringite, metaettringite, and $\mathrm{Ca}-\mathrm{Al}-\mathrm{NO}_{3} \mathrm{LDHs}$ were successfully synthesized from concrete sludge. The CS-ettringite showed some ability to remove fluoride, although it was not as effective as the CS-metaettringite and CS-LDH. The CS-metaettringite showed high removal ability for borate and fluoride. It reduced the borate concentration from 100 to $6.3 \mathrm{mg} \mathrm{B} / \mathrm{L}$ and the fluoride concentration from 300 to $14.5 \mathrm{mg}$ F/L. The CS-LDH showed high removal ability for fluoride and especially for chromate, reducing the 
fluoride concentration from 300 to $14.5 \mathrm{mg} \mathrm{F} / \mathrm{L}$ and the chromate concentration from 180 to $0.4 \mathrm{mg} \mathrm{Cr} / \mathrm{L}$.

\section{REFERENCES}

[1] D. Wohan and C. U. Pittman Jr., "Arsenic removal from water/wastewater using adsorbents," Journal Hazardous Materials, vol. 142, pp. 1-53, 2007.

[2] P. A. Brown, S. A. Gill, and S. J. Allen, "Metal removal from waste water using peat," Water Research, vol. 34, pp. 3907-3916, 2000

[3] M. P. Koivula, K. Kujala, H. Rönkkömäki, and M. Mäkelä, "Sorption of $\mathrm{Pb}(\mathrm{II}), \mathrm{Cr}(\mathrm{III}), \mathrm{Cu}(\mathrm{II}), \mathrm{As}$ (III) to peat, and utilization of the sorption properties in industrial waste landfill hydraulic barrier layers," Journal of Hazardous Materials, vol. 164, pp. 345-352, 2009.

[4] F. Kaczala, M. Marques, and W. Hogland, "Lead and vanadium removal from a real industrial wastewater by gravitational settling/sedimentation and sorption onto Pinus sylvestris," Bioresource Technology, vol. 100, pp. 235-243, 2009.

[5] M. A. Barakat, Y. T. Chen, and C. P. Huang, "Removal of toxic cyanide and $\mathrm{Cu}$ (II) ions from water by illuminated $\mathrm{TiO}_{2}$ catalyst," Applied Catalysis B, vol. 53, pp. 13-20, 2004.

[6] V. Boonamnuayvitaya, C. Chaiya, W. Tanthapanichakoon, and S. Jarudilokkul, "Removal of heavy metals by adsorbent prepared from pyrolyzed coffee residues and clay," Separation and Purification Technology, vol. 35, pp. 11-22, 2004.

[7] D. Sud, G. Mahajan, and M. P. Kaur, "Agricultural waste material as potential adsorbent for sequestering heavy metal ions from aqueous solutions," Bioresource Technology, vol. 99, pp. 6017-6027, 2008.

[8] P. Catalfamo, I. Arrigo, P. Primerano, and F. Corigliano, "Efficiency of a zeolitized pumice waste as a low-cost heavy metals," Journal of Hazardous Materials, vol. 134, pp. 140-143, 2006.

[9] S. C. B. Myneni, S. J. Traina, T. J. Logan, and G. A. Waychunas, "Oxyanion behavior in alkaline environments: sorption and desorption of arsenate in ettringite," Environmental Science Technology, vol. 31, pp. 1761-1768, 1997.

[10] M. Zhang, and E. J. Reardon, "Removal of B, Cr, Mo, and Se from wastewater by incorporation into hydrocalumite and ettringite," Environmental Science and Technology, vol. 37, pp. 2947-2952, 2003.

[11] Q. Zhou, E. E. Lachowski, and F. P. Glasser, "Metaettringite, a decomposition product of ettringite," Cement and Concrete Research, vol. 34, pp. 703-710, 2004

[12] J. Pourchez, F. Valdivieso, P. Grosseau, R. Guyonnet, and B. Guilhot, "Kinetic modeling of the thermal decomposition of ettringite into metaettringite," Cement and Concrete Research, vol. 36, pp, 2054-2060, 2006.

[13] T. Hongo, Y. Tsunashima, Y. Sakai, A. Iizuka, and A. Yamasaki, "A comparative borate adsorption study of ettringite and metaettringite," Chemistry Letters, vol. 40, pp. 1269-1271, 2011.

[14] M.Meyn, K. Beneke, and G. Lagaly, "Anion-exchange reactions of layered double hydroxides," Inorganic Chemistry, vol. 29, pp. 5201-5207, 1990.

[15] F. Millange, R. I. Walton, L. Lei, and D. O'Hare, "Efficient separation of terephthalate and phthalate anions by selective ion-exchange intercalation in the layered double hydroxide $\mathrm{Ca}_{2} \mathrm{Al}(\mathrm{OH})_{6} \cdot \mathrm{NO}_{3}$ $2 \mathrm{H}_{2} \mathrm{O}$," Chemistry of Materials, vol. 12, pp. 1990-1994, 2000.

[16] F. Cavani, F. Trifiró, and A. Vaccari, "Hydrotalcite-type anionic clay: preparation, properties and applications," Catalysis Today, vol. 11, pp. 173-301, 1991.

[17] A. I. Khan and D. O'Hare, "Intercalation chemistry of layered double hydroxides: recent developments and applications," Journal of Materials Chemistry, vol. 12, pp. 3191-3198, 2001.

[18] K. Goh, T. Lim, and Z. Dong, "Application of layered double hydroxides for removal of oxyanions: A review," Water Research, vol. 42, pp. 1343-1368, 2008.

[19] T. Sasaki, Y. Sakai, T. Hongo, A. Iizuka, and A. Yamasaki, "Preparation of a solid adsorbent derived from concrete sludge and its boron removal performance," Industrial and Engineering Chemistry Research, vol. 51, pp. 5813-5817, 2012.

[20] Y. Tsunashima, A. Iizuka, J. Akimoto, T. Hongo, and A. Yamasaki, "Preparation of sorbents containing ettringite phase from concrete sludge and their performance in removing borate and fluoride ions from waste water," Chemical Engineering Journal, vol. 200-202, pp. 338-343, 2012.

[21] Q. Zhou, E. E. Lachowski, and F. P. Glasser, "Metaettringite, a decomposition product of ettringite," Cement and Concrete Research, vol. 34, pp. 703-710, 2004.

[22] T. Hongo, Y. Tsunashima, Y. Sakai, A. Iizuka, and A. Yamasaki, "A comparative borate adsorption study of ettringite and metaettringite," Chemistry Letters, vol. 40, pp. 1269-1271, 2011.

[23] H. K. Roobottom, H. D. B. Jenkins, J. Passmore, and L. Glasser, "Thermochemical radii of complex ions," Journal of Chemical Education, vol. 76, pp. 1570-1573, 1999.

Teruhisa Hongo is an assistant professor at Waseda University. He received his doctor's degree from Tokyo Institute of Technology, Japan. His major field is Inorganic Materials Chemistry. His area of interest includes adsorbents for harmful ions, catalyst and photocatalyst for decomposition of volatile organic compounds, and recycle process of inorganic waste. 